IRA-International Journal of Management \&

Social Sciences

ISSN 2455-2267; Vol.11, Issue 01 (April 2018)

Pg. no. 17-25.

Institute of Research Advances

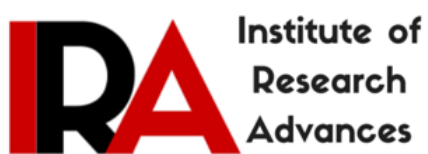

http://research-advances.org/index.php/RAJMSS

\title{
The Impacts of Competence, Work Motivation, Job Satisfaction and Organizational Commitment on Lecturers' Performance
}

\author{
H. Mursalim Umar Gani ${ }^{1}$, Muhammad Nur ${ }^{2}$, H. Syahrir Mallongi ${ }^{3}$, H. Rusjdin ${ }^{4}$ \\ 1, 2, 3, ${ }^{4}$ Faculty of Economics, University of Indonesia Muslim, Indonesia.
}

Type of Review: Peer Reviewed.

DOI: http://dx.doi.org/10.21013/jmss.v11.n1.p2

\section{How to cite this paper:}

Gani, H.M.U., Nur, M., Mallongi, H.S., Rusjdin, H. (2018). The Impacts of Competence, Work Motivation, Job Satisfaction and Organizational Commitment on Lecturers' Performance. IRA-International Journal of Management \& Social Sciences (ISSN 2455-2267), 11(1), 17-25. doi:http://dx.doi.org/10.21013/jmss.v11.n1.p2

(C) Institute of Research Advances.

\section{(cc) BY-NO}

This work is licensed under a Creative Commons Attribution-Non Commercial 4.0 International License subject to proper citation to the publication source of the work.

Disclaimer: The scholarly papers as reviewed and published by the Institute of Research Advances (IRA) are the views and opinions of their respective authors and are not the views or opinions of the IRA. The IRA disclaims of any harm or loss caused due to the published content to any party.

Institute of Research Advances is an institutional publisher member of Publishers Inter Linking Association Inc. (PILA-CrossRef), USA. The institute is an institutional signatory to the Budapest Open Access Initiative, Hungary advocating the open access of scientific and scholarly knowledge. The Institute is a registered content provider under Open Access Initiative Protocol for Metadata Harvesting (OAI-PMH).

The journal is indexed \& included in WorldCat Discovery Service (USA), CrossRef Metadata Search (USA), WorldCat (USA), OCLC (USA), Open J-Gate (India), EZB (Germany) Scilit (Switzerland), Airiti (China), Bielefeld Academic Search Engine (BASE) of Bielefeld University, Germany, PKP Index of Simon Fraser University, Canada. 


\begin{abstract}
This study aims to examine and analyze the effect of the competence, motivation and job satisfaction and organizational commitment of lecturer's performance. Research was conducted in private Islamic university in Makassar. The population in this research is the foundation of the entire faculty as many as 1,264 people using Slovin formula samples were obtained 176 respondents. Data were analyzed using the Structural Equation Model using AMOS aid 18. The results prove that the competence and no significant negative effect on lecturers commitment. The other variables effect shows that between work motivation and job satisfaction positive and significant impact on organizational commitment. At the end found that the competence, motivation, job satisfaction and organizational commitment has a positive significant effect on the lecturer's performance.
\end{abstract}

Keywords: Competence, work motivation, job satisfaction, commitment, lecturer performance

\title{
Introduction
}

The success of an organization in developing its dynamics depends on the competence, motivation, job satisfaction, organizational commitment and performance of individuals in an organization. The variable will be the core of the dynamics of the organization that developed and developing (Sulastyo, 2009). Addressing the importance of organizational dynamics, then any Islamic University, both shaped the university and high school, seeks to improve the performance of lecturers through the organization's commitment to improve the effect of competence, motivation and job satisfaction as an important and necessary in carrying out their work activities. Robbins (2007) states that the competent human resources are always motivated to meet the corresponding job satisfaction and organizational commitment to the performance achieved in the organization. Banham (2005) competence, motivation and job satisfaction influence each other in achieving organizational commitment and lecturer's performance. Maslow, Herzberg and McClelland cited in Tohardi (2008) stated motivation was essential to improve competence and job satisfaction in achieving the commitment and performance, motivation possessed was the hope to realize the individual who is competent, satisfied in the work according to the commitment and performance are achieved. Work motivation is relevant to their competence and appropriate job satisfaction organizational commitment and performance. The Competence, work motivation, job satisfaction, organizational commitment and individual performance is a key to success in realizing individual in the organization of Human Resources (Nelson, 2007).

Based on the observation of the phenomenon of the competence of lecturers found in the fact that the knowledge of lecturers on subjects that are taught are still low does not correspond to the quality orientation, problem solving skills, planning skills, teamwork and self-learning capacity. As a result of the still low competence lead lecturer organizational commitment and performance decline. The same thing can also be seen that the motivation of lecturers in teaching has not been demonstrated motivation as expected. Lecturer many complained about the low provision of remuneration in the form of compensation for a career that is occupied, do not get improved working conditions as expected in support of his career, rarely get a promotion according to rank academic and functional position and the absence of an opportunity to develop work in the field of higher education,

Naturally this led to low motivation and organizational commitment of faculty performance decreases. Includes found no phenomenon that job satisfaction experienced by lecturers not being met in accordance with the progress of work expected, the ability of the advantages of educating, not able to develop a teaching system that is easy to understand, difficult to develop a reputation for exemplary levels of employment and low employment. This is why the professors often do not feel fulfilled expectations of satisfaction in his profession as a lecturer. As a result of unfulfilled job satisfaction, organizational commitment decreased and faculty performance also declined. The lack of contribution effect of competence, motivation and job satisfaction are owned by professors, directly and indirectly affect the organization's commitment. This is evident from the lack of affective commitment to promote the organization, lecturer less committed to comply with the normative rules of the organization, less committed to the development of the organization and are not able to maintain the quality improvement organization. The directly of low the organizational commitment has a give effect to the declining the lecturer performance. The Performance 
decreases lecturers can be seen from the achievement of the work of lecturers is not appropriate in terms of quantity, quality, and hours of work, occupational risks and thoroughness of the work undertaken by the lecturer. A consideration is improving the lecturer performance enhancement through improved organizational commitment to increase the effect of competence, motivation and job satisfaction lecturer at the College of Islamic Makassar.

\section{Literature Review}

\section{Human Resource Management}

Management word comes from the English "management" developed from the word to manage, which means arranging or managing. The word manage itself comes from the Italian, maneggio adopted from Latin managiare derived from the word manus meaning of hand. Management concept is not easy to define, hitherto undiscovered management definitions that really can be universally accepted. Barry (2006: 15-16) states that management is working with people to achieve organizational goals with the performance of the functions of planning, organizing, preparation of personnel (staffing), direction or leadership (leading) and supervisory (controlling). Management is essentially an effort to organize everything (resources) to achieve the goals of the organization; this is a grand theory of Terry (2008: 46) states that management is an umbrella of human resources which regulates the potential of human resources in an organization to achieve organizational goals. From the description it appears that the management there are two important things that people and organizations. Man is a potential running events management and organization is a vehicle to channel potential of human resources to achieve common prosperity.

\section{Competence}

Explain the importance of human resource competencies; it refers to the theoretical ability. Theory capability introduced by Terry (2005: 151) states that any competent human resources. Competence are ideal if supported by quality orientation, problem solving skills, planning skills, team work and self-learning capacity. Every human being has the potential, therefore the potential to be considered in improving the human resources competence. The core competencies are developed according to the theory of self-access introduced by Morgan cited in Hasibuan (2005: 19) states that every person has access to knowledge, skills, the journey of life, and future orientation means on the competence of a person. This was later simplified that the translation of knowledge will be achieved through education. The Each proficiency is determined by the skill level occupied. The journey of life is basically an appreciation of the experience faced by a person and future orientation is determined by the progress of work. This view of competence is also expressed by Roger cited in Harijaya (2004: 39) which introduces the theory of selfdevelopment cycle. This theory basically introduced that every developing human resources and move forward, regardless of their four most pertinent elements are elements of quality orientation, problem solving skills, planning skills, teamwork, and self-learning capacity. Each individual human resources education is supported by the skills of the human resources that are reliable. A human resources skill supported by a mature work experience is quality human resources.

\section{Work Motivation}

Motivation comes from the word "movere" which means "impulse or motive power". This motivation can only be given to humans, especially to subordinates or followers. Motivation questioned how encouraging morale subordinates, so that they would work hard to provide all the capabilities and skills to achieve organizational goals. The formulation of motivation by (Robbins, 1999: 50) says that motivation is high willingness to make efforts to achieve organizational goals, conditioned by the effort's ability to meet the needs of a particular individual in accordance with the work. According to Rivai (2007: 665) the term motivation is literally interpreted as an impulse that arises in a person consciously or unconsciously to act with a certain purpose. The term motivation is also often interpreted as a boost or power of motion, causes a person to perform various activities with a specific purpose

\section{Job Satisfaction}

According to Robbins (2007) theories on job satisfaction, there are three kinds of commonly encountered are:

\section{Discrepancy Theory}

Satisfaction or dissatisfaction felt by individuals is the result of a comparison or gaps that do by you against a wide range of things that have been obtained from work and he hopes. Satisfaction will be felt by the individual if the 
differences or gaps between individual personal standards with the data obtained from small jobs, otherwise the dissatisfaction will be felt by the individual if the differences or gaps between individual personal standards with the data obtained from the great work.

\section{Equity Theory}

A person will be satisfied or not satisfied depending on whether he felt justice or not on a situation. Feelings of equity or inequity on a situation of a person obtained by comparing themselves with others in its class, work together, as well as other local.

\section{Two Factor Theory}

The principle of this theory is that satisfaction and job dissatisfaction are two different things. According to this theory, the job characteristics can be grouped into two categories, one is called dissatisfied or hygiene factors and others called the satisfiers or motivators.

\section{Organizational Commitment}

Organizational commitment is a condition of positive behavior through loyalty to the organization of employment. According Gimbart (2008: 520) organizational commitment is a commitment that appears not to be loyalty passive, but involves active relationship with the organization of work of the (organizational commitment, namely a commitment roommates rise not just to be passive loyalty, but to participate of active relations with organization). Luthans (2005: 64) defines organizational commitment as the embodiment of the totality of the individual loyalty to the organization's identity. Wu and Norman (2006) regard the organization's commitment as a totality of value orientations loyalty to the organization. Similarly, Ibrahim (2008: 525) suggests three principle characteristics of organizational commitment, namely: (1). the strong belief about the organization, (2). Defend themselves in order to remain a member of the organization, (3). Trying hard as part of the organization's members.

\section{Lecturer Performance}

Understanding of performance as one of the terms that are widely used in the scientific study of human resource management, application performance based on several theories that give substance to the meaning of the performance. Theoretical results, the theory of interest, devotion theory and optimization theory works. This theory is the underlying theory in understanding the notion of performance. Theoretical results presented by Kaplan and Norton (2006: 66) states that the performance is the actualization maximum result to achieve organizational goals. The aim is to provide an understanding that any work that is achieved is the embodiment of the actualization of the individual or group of people who perform the activity.

The theory put forward by Warritten (2007: 191) states that the performance is a continuous activity in generating purposes. Any activity undertaken in a planned and sustainable basically embodies the performance measures to produce a goal. Performance can be interpreted as the result of the actualization of the goal. Theory dedication of prospective understanding of the performance, according to Bourneta (2008: 39) that the performances are the embodiment of a real dedication in facing and achieve a favorable result. The essence of this statement is the term devotion that provides an understanding that through the dedication of an individual is able to carry out its activities in earnest to achieve a favorable outcome.

\section{Methods}

This study was designed to answer the problems are formulated and the goals to be achieved and to test the hypothesis. The research was carried out for approximately three months from September to November 2017. The research was conducted in the city of Makassar precisely at the Islamic private University in Makassar. The goal is to determine the effect of competence, motivation, job satisfaction and organizational commitment on lecturer performance. Types and sources of data in this research is quantitative data consist of primary data and secondary data. The technique of collecting data is an observation, questionnaires and documentation. The population in this study were as many as 1,264 people, consisting of Muslim University Makassar A total of 669 people, the University of Muhammadiyah Makassar as many as 435 people, Islamic University of Makassar as many as 120 people and Arabic and Islamic high school (STIBA) Makassar as many as 40 people. Samples obtained using the 
formula Slovin 176 respondents. Data analysis methods used in explaining the phenomenon in this research is descriptive statistical analysis and the analysis of Structural Equation Modeling (SEM).

\section{Analysis and Discussion}

Based on the method of determining the value of the model, the first model testing variables are grouped into exogenous variables and endogenous variables). Exogenous variables is a variable whose value is determined outside the model while the endogenous variable is a variable whose value is determined by an equation or model relationship is formed. Included in this group of exogenous variables is the measurement of competence, motivation and job satisfaction while those classified as an endogenous variable is organizational commitment and performance of lecturers. The model is said to be good when the hypothetical theoretical model development supported by empirical data. Detailed SEM analysis results are shown in Figure 1 below:

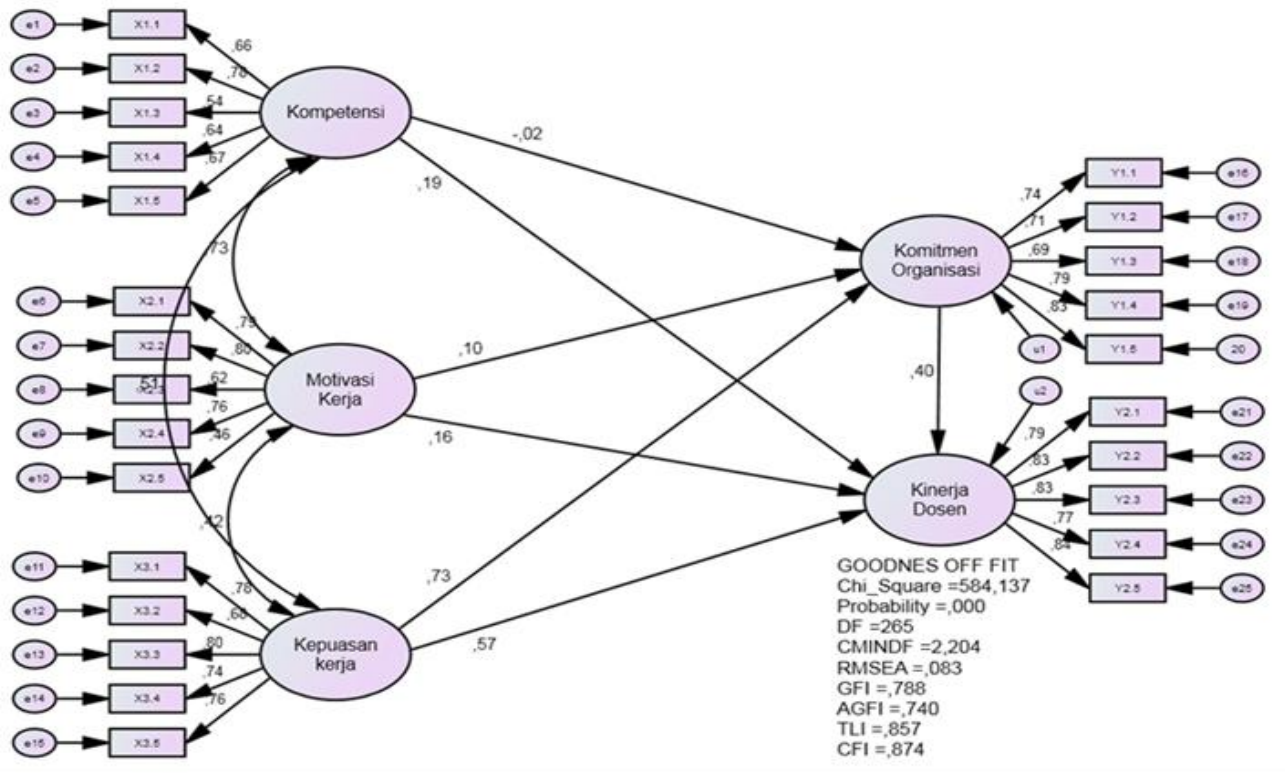

Figure 1

First Model

The results model test are presented in Figure 1 above are evaluated based on the goodness of fit indices are presented in the following table with the criteria of the model as well as critical values that have compatibility data.

Table 1. Evaluation criteria Goodness of Fit Indices Overall Model

\begin{tabular}{|c|c|c|c|}
\hline Goodness of fit index & Cut-off Value & Results Model * & Description \\
\hline$\square^{2}$ - Chi-square & small Expected & $584.137>(0.05: 265=303.670)$ & Marginal \\
\hline Probability & $\geq 0: 05$ & 0000 & Marginal \\
\hline CMIN / DF & $\leq 2.00$ & 2,204 & Marginal \\
\hline RMSEA & $\leq 0.08$ & 0083 & Marginal \\
\hline GFI & $\geq 0.90$ & 0788 & Marginal \\
\hline AGFI & $\geq 0.90$ & 0.740 & Marginal \\
\hline TLI & $\geq 0.95$ & 0.857 & Marginal \\
\hline CFI & $\geq 0.95$ & 0874 & \\
\hline
\end{tabular}


From the evaluation of the model showed of the eight criteria of goodness of fit indices seen from the eight criteria proposed, it appears no one has met the criteria, given one testing SEM is testing the model, then there needs to be proof of whether there is a fit between the model with the data through the fulfillment of criteria values of goodness of fit indices that were modified models by performing the correlation between error indicator according to the instructions of the modification indices on the condition that the modification is done without changing the meaning of the relationship between variables. The results of the analysis after the final model obtained are as follows:

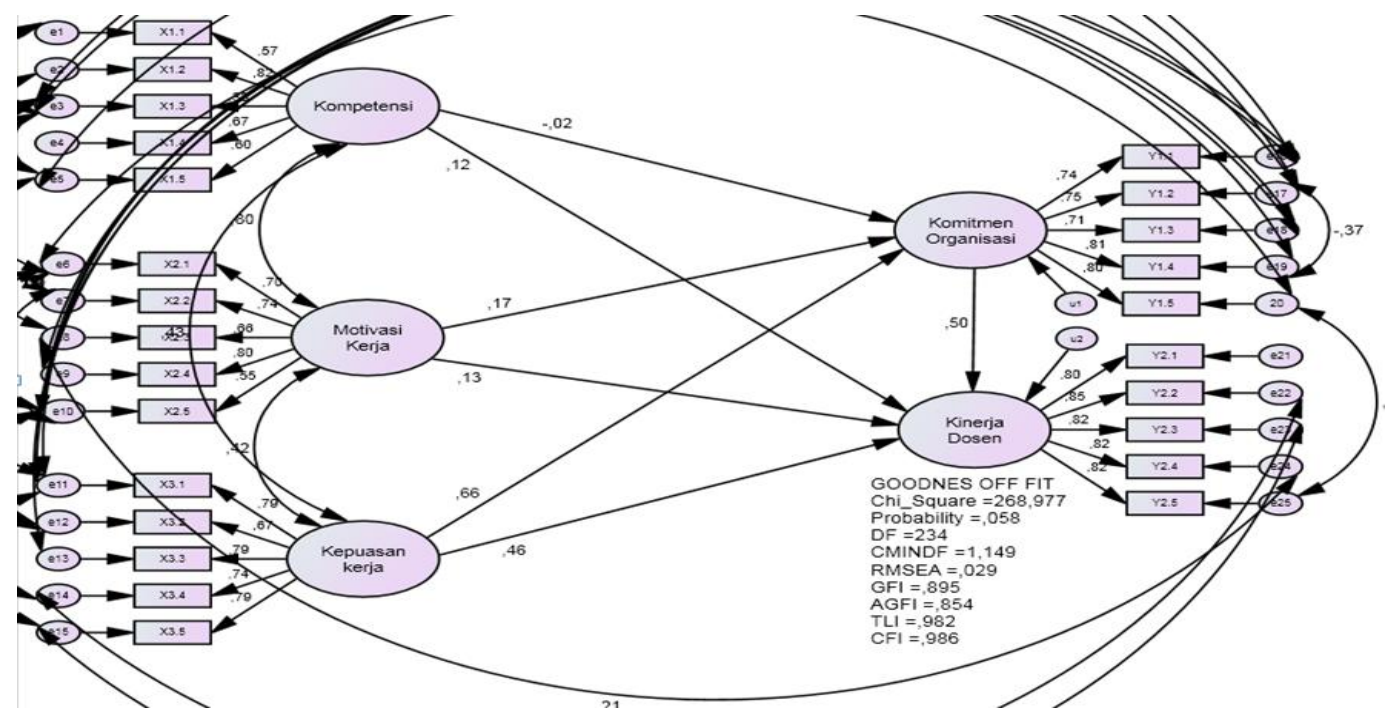

Figure 2

Final Model

The model test results are presented in Figure 2 above are evaluated based on the goodness of fit indices are presented in the following table with the criteria of the model as well as critical values that have compatibility data.

Table 2

Evaluation criteria of Goodness of Fit Indices Overall Model

\begin{tabular}{|c|c|c|c|}
\hline Goodness of fit index & Cut-off Value & Results Model $*$ & Description \\
\hline Chi-square & small Expected & $268.977<(0.05: 234=270.684)$ & Good \\
\hline Probability & $\geq 0: 05$ & 0.058 & Good \\
\hline CMIN / DF & $\leq 2: 00$ & 1.149 & Good \\
\hline RMSEA & $\leq 0: 08$ & 0.029 & Good \\
\hline GFI & $\geq 0.90$ & 0895 & Marginal \\
\hline AGFI & $\geq 0.90$ & 0854 & Marginal \\
\hline TLI & $\geq 0.95$ & 0.982 & Good \\
\hline CFI & $\geq 0.95$ & 0.986 & Good \\
\hline
\end{tabular}

From the evaluation of the eight criteria model shows a goodness of fit indices there were six met the criteria, so that the overall model can be said to have been in accordance with the data and can be analyzed further. Based on empirical models proposed in this study can be tested against the hypothesis put forward by testing the path 
coefficients in structural equation modeling. Table 3 is a hypothesis by looking at the p-value, if the p-value less than 0.05 then the relationship between significant variables. The test results are presented in the following table:

Table 3. Hypothesis Testing

\begin{tabular}{|c|c|c|c|c|c|c|}
\hline \multirow{2}{*}{ Нyр } & \multirow{2}{*}{ Independent } & \multirow{2}{*}{ Dependent } & \multicolumn{4}{|c|}{ Direct Effect } \\
\hline & & & Standardize & Critical ratio & p-value & Description \\
\hline $\mathrm{H}_{1}$ & Competence & $\begin{array}{c}\text { Organizational } \\
\text { Commitment }\end{array}$ & -0.015 & 0.110 & 0.913 & $\begin{array}{c}\text { Negative } \\
\text { insignificant }\end{array}$ \\
\hline $\mathrm{H}_{2}$ & Work Motivation & $\begin{array}{c}\text { Organizational } \\
\text { Commitment }\end{array}$ & 0.169 & 2.194 & 0.029 & $\begin{array}{c}\text { Significant } \\
\text { Positive }\end{array}$ \\
\hline $\mathrm{H}_{3}$ & Job satisfaction & $\begin{array}{c}\text { Organizational } \\
\text { Commitment }\end{array}$ & 0.660 & 7.593 & 0.001 & $\begin{array}{c}\text { Positive } \\
\text { Significant }\end{array}$ \\
\hline $\mathrm{H}_{4}$ & Competence & $\begin{array}{c}\text { Lecturer } \\
\text { performance }\end{array}$ & 0.120 & 2.129 & 0.034 & $\begin{array}{c}\text { Positive } \\
\text { Significant }\end{array}$ \\
\hline $\mathrm{H}_{5}$ & work Motivation & $\begin{array}{c}\text { Lecturer } \\
\text { performance }\end{array}$ & 0.129 & 2.018 & 0.045 & $\begin{array}{c}\text { Positive } \\
\text { Significant }\end{array}$ \\
\hline $\mathrm{H}_{6}$ & Job satisfaction & $\begin{array}{c}\text { Lecturer } \\
\text { performance }\end{array}$ & 0.458 & 5.707 & 0.001 & $\begin{array}{c}\text { Positive } \\
\text { Significant }\end{array}$ \\
\hline $\mathrm{H}_{7}$ & $\begin{array}{l}\text { organizational } \\
\text { commitment }\end{array}$ & $\begin{array}{c}\text { Lecturer } \\
\text { performance }\end{array}$ & 0.500 & 5.740 & 0.001 & $\begin{array}{c}\text { Positive } \\
\text { Significant }\end{array}$ \\
\hline \multicolumn{7}{|c|}{ Indirect Effect } \\
\hline & Independent & Dependent & Intervening & Coefficien & $p$-value & Description \\
\hline $\mathrm{H}_{8}$ & Competence & $\begin{array}{c}\text { Lecturer } \\
\text { performance }\end{array}$ & $\begin{array}{c}\text { Organizational } \\
\text { commitment }\end{array}$ & -0.008 & 0.914 & $\begin{array}{l}\text { Negative } \\
\text { insignificant }\end{array}$ \\
\hline $\mathrm{H}_{9}$ & work Motivation & $\begin{array}{c}\text { Lecturer } \\
\text { performance }\end{array}$ & $\begin{array}{c}\text { Organizational } \\
\text { commitment }\end{array}$ & 0,085 & 0,040 & $\begin{array}{l}\text { Positive } \\
\text { Significant }\end{array}$ \\
\hline $\mathrm{H}_{10}$ & Job satisfaction & $\begin{array}{c}\text { Lecturer } \\
\text { performance }\end{array}$ & $\begin{array}{c}\text { Organizational } \\
\text { commitment }\end{array}$ & 0.330 & 0.001 & $\begin{array}{l}\text { Positive } \\
\text { Significant }\end{array}$ \\
\hline
\end{tabular}

From all seven models hypothesized direct path, there is a significant six lanes and one lane is not significant and the three lanes indirect one insignificant. The interpretation of Table 17dapat described as follows:

1. Competency have no significant negative influence on organizational commitment with a $\mathrm{p}$-value $=0913>0.05$ with a coefficient value of -0015 , this coefficient indicates that the competence of both owned by the lecturer does not increase because of the potential organizational commitment of lecturers a growing number of other organizations that provide a promising offer in addition to the organization so that more potential lecturers diminishing commitment to the organization.

2. Work motivation has significant influence on job satisfaction with a p-value $=0.029>0.05$ with a coefficient of 0.169 , this coefficient shows that if a person is getting better motivation to work the organization's commitment will also be good.

3. Job satisfaction has a significant positive effect on organizational commitment with a p-value $=0.000>0.05$ with a coefficient of 0.660 , this coefficient indicates that the better the job satisfaction organizational commitment will also be good.

4. Competence has a significant positive effect on the performance of faculty with a p-value $=0.034>0.05$ with a coefficient of 0.120 , this means that the better the competence of the faculty performance also will be better

5. Work motivation has a significant positive effect on the lecturer performance with a p-value $=0.045>0.05$ with a coefficient value of 0129 , this coefficient indicates that the higher the motivation to work, the performance of lecturers will also be higher. Work motivation also indirect effect on the performance of lecturers through job satisfaction. This means that lecturers who have high motivation to work will have job satisfaction is getting better and ultimately the performance of lecturers will get better 
6. Job satisfaction has a significant positive effect on the lecturer performance with a p-value $=0.000>0.05$ with a coefficient value of 0458 , this coefficient shows that the higher the job satisfaction of faculty performance will be higher as well.

7. The organizational commitment has a positive significant effect on the lecturer performance with a $\mathrm{p}$-value $=$ $0.001>0.05$ with a coefficient of 0.500 , the coefficient indicates that the higher faculty commitment to the organization, the performance of lecturers will be higher as well.

8. Competence had a negative and no significant effect on the lecturer performance as a mediating role of organizational commitment to the value of the indirect influence of 0.914 .

9. Work motivation positive and significant effect on the lecturer's performance as a mediating role of organizational commitment to the value of the indirect effect of 0,040 .

10. Job satisfaction positive and significant effect on the lecturer's performance a mediating role of organizational commitment to the value of the indirect influence of 0.001 .

The table 3 it can be seen that there is a path and a significant influence is not significant. Thus the hypothesis:

$\mathrm{H}_{2:} \quad$ Motivation has an effect on organizational commitment

$\mathrm{H}_{3:}$ Job satisfaction has an effect on organizational commitment

$\mathrm{H}_{4:}$ Competence has an effect on lecturer's performance

$\mathrm{H}_{5}$ : Motivation has an effect on lecturer's performance.

$\mathrm{H}_{6:} \quad$ Job satisfaction has an effect on lecturer's performance

$\mathrm{H}_{7}$ : Organizational commitments have an influence on lecturer's performance

$\mathrm{H}_{9}$ : Motivation has an influence on the lecturer's performance as a mediating role of organizational commitment

$\mathrm{H}_{10}$ : Job satisfaction has an influence the lecturer's performance as a mediating role of organizational commitment

Thus, the eighth the hypothesis is accepted and supported by empirical facts.

As for the hypothesis:

$\mathrm{H}_{1:}$ Competency and no significant negative effect on organizational commitment.

$\mathrm{H}_{8}$ : Competency has a negative impact and no significant effect on the performance of lecturers through organizational commitment

Thus, the second hypothesis cannot be accepted and are not supported by empirical facts.

The result of the analysis has been discussed in demonstrating the influence of variables constructs related to this study found the following results:

1. Seeing the results of tests on variables observed, it can be stated that job satisfaction variables provide a dominant influence on organizational commitment Islamic college private in Makassar means that lecturers in improving organizational commitment is strongly influenced directly by the faculty job satisfaction over the success achieved in providing the best teaching.

2. Looking at the results of testing on the independent variables observed, it can be stated that job satisfaction variables provide a dominant influence on the performance of university teachers of Islam in Makassar means that lecturers in improving performance is highly influenced directly by the form of job satisfaction is inside and outside of oneself lecturers.

3. Job satisfaction becomes important in determining job satisfaction achievement of private Islamic university professor in Makassar, that more fulfilled faculty job satisfaction then the pushing professors to improve its performance.

4. Looking at the results of testing on the independent variables observed were negative and no significant effect on organizational commitment is variable competence, it does give an indication that the higher the competence which is owned by the university professor of Islamic private in Makassar, the lower the commitment he showed in Universities Private in Makassar, meaning that the higher the competency of lecturers Colleges in Makassar, the lower the contribution in enhancing the organizational commitment of lecturers. 


\section{Conclusion}

1. Competency has a negative and no significant effect on organizational commitment. Competence of lecturers contribute directly to the organizational commitment that directly negative and not significant.

2. Work motivation of lecturers has positive and significant impact on organizational commitment. High working motivation lecturer can affect the improvement of organizational commitment, both directly and indirectly.

3. Job satisfaction has a positive and significant impact on organizational commitment. Actualization of getting job satisfaction can be implemented into the organization's commitment, the better so as to provide a positive and significant influence.

4. Competence has a positive and significant impact on the performance of lecturers. Competences of lecturers are at a high level so as to give effect to the improved performance of lecturers.

5. Work motivation gives positive and significant impact on the performance of lecturers. Lecturers who have a high motivation to produce high performance.

6. Job satisfaction has a positive and significant impact on performance. Lecturers are satisfied in the work shown by what they earned has been proven to improve the performance of their piece.

7. Organizational commitment has positive and significant impact on performance. Lecturers who have a high organizational commitment shown to improve the performance they show.

8. Competence has a negative effect and no significant effect on the performance of lecturers through organizational commitment. That is the competence of lecturers need to be optimized in accordance with the level of organizational commitment that they show that the higher the performance shown.

9. Work motivation has a positive and significant impact on the performance through organizational commitment means a high work motivation lecturer in line with the increase in organizational commitment they have shown that the higher the performance shown.

10. Job satisfaction has a positive and significant influence on performance through organizational commitment means the perceived job satisfaction lecturers are in accordance with the expectations of lecturers and in line with organizational commitment they have shown that the higher the performance shown.

\section{References}

[1] Banham, J. (2005). Development of Human Resource Management. Published by Prentice Hall, New York.

[2] Barry, Lays. (2006). Human Resource Management. Published by McGraw Hill, Ohio. Beer, Keenoy and Spector, Anthony., 2004. Human Resource Management and Development. London, Sage.

[3] Bourneta, Nelly. (2008). Human Resource Management in Strength Quality Prospective. Published McGraw Hill, New York.

[4] Gimbart, John D. (2008). Behavior Principles in Organization Everyday Life. 2nd ed. Englewood Cliffs, Prentice Hall, New Jersey.

[5] Harijaya, Shadik. (2004). Competence Personal Development Towards Optimal. Publisher Harvarindo, Jakarta.

[6] Hasibuan, P. Malaju. (2005). Management Integrated Human Resources. Publisher Gunung Agung, Jakarta.

[7] Ibrahim, MT. (2008). Education Based System and Intelligence Competency Training. Penerit Gramedia Pustaka, Jakarta.

[8] Kaplan, R. S., and Norton, D. P. (2006). Alignment: Using the balanced scorecard to create corporate synergies. Harvard Business Press.

[9] Luthans, Fred. (2002). Organizational Behavior, 7th ed, McGraw-Hill, New York

[10] Nelson, Neil. (2007). Human Resource Management In Strength Quality Prospective. Published McGraw Hill, New York.

[11] Rival, Veithzal. (2007). PerformanceAppraisal.PT Raja Grafindo Perseda, Jakarta.

[12] Robbins, Stephen P. (1999). The set of theories of motivation. Volume I, Second Edition, Publisher PT.Prenhallindo, Jakarta.

[13] Robbins, Stephen P. (2007). Organizational Behavior. Tenth Edition. Complete Edition. Publisher PT. Macanan Jaya Cemerlang, Jakarta.

[14] Sulastyo, Nazir. (2006). Motivation in Human Resources Overviewsatisfaction.Publisher, Jakarta.

[15] Terry, GR. (2008). Human Resource Management. Published by McGraw Hill, Ohio.

[16] Thompson, Smith. (2004). The Responsibility of Job in Company. Published by John Wiley and Sons, USA.

[17] Tohardi, Ahmad. (2008). Practical Understanding of Human Resource Management. Publisher University Tanjungpura, Mandar Maju, Bandung

[18] Warritten, Harold. (2007). Essentials of Management. Fifth Edition, McGraw Hill, Inc., Singapore. 